Technical Paper

\title{
Life Cycle Analysis of Environmental Load from Polyvinyl Chloride Products
}

\author{
Katsuhito NAKAZAWA *1, Seiji SAKAI*2, Keiichi KATAYAMA*3 ${ }^{*}$, and Itaru YASUI *4 \\ (Received November 30, 2006)
}

\author{
ポリ塩化ビニル製品のライフサイクルにおける環境負荷分析 \\ 中澤克仁 ${ }^{* 1}$ ，酒井清次*2，片山恵一*3，安井 至*4
}

\begin{abstract}
Polyvinyl chloride (PVC) is a material with advantages of productivity, recyclability and economy, and that is applied to various products such as pipes, films and electric cables. On the other hand, it is limited that the PVC products are used because of excessive fear to chemical substances generated by the combustion, and to endocrine disrupters from the plasticizer. In this study, life cycle inventories of a pipe for water supply as rigid PVC products and an agro-film as flexible PVC products were analyzed, and the comparisons with alternative products were investigated in terms of environmental load, that is, energy consumption, $\mathrm{CO}_{2}$ emission, $\mathrm{SO}_{\mathrm{x}}$ emission, $\mathrm{NOx}$ emission and solid waste.

As results, it was shown that the energy consumption from the pipe for water supply made from PVC was smaller than that from the alternative pipe for water supply. In addition, the environmental load caused by the PVC pipe was remarkably decreased by raising a ratio of Pipe to Pipe recycling. Considering the durability of each agro-film, the energy consumption of the agro-film made from PVC was the largest in all agro-films. It is necessary to extend the life period of PVC films in order to reduce the environmental load.
\end{abstract}

\section{Key Words}

PVC, Pipe for water supply, Agro-film, Alternative product, Life cycle inventory analysis

\section{1. はじめに}

ポリ塩化ビニル (以下, PVC) は, 耐久性, 加工性, 電気絶 縁性，難燃性等に優れた素材であることから，年間 215 万t のPVC樹脂が生産されおり, これはポリエチレン, ポリプロ ピレンに次ぐ生産量となっている1)。このほとんどが食塩電解 法により製造される苛性ソーダ $(\mathrm{NaOH})$ の副産物である塩素 $\left(\mathrm{Cl}_{2}\right)$ を原料としており，この需要と供給のバランスを保ち続 けることは, 素材産業におけるエネルギー・コスト増大を避 ける意味でも必要不可欠な材料となっている。また，使用済 みPVC製品の多くが床材やパイプ等へマテリアルリサイクル されている現状を考えると, 今後の循環型社会形成の促進を

* 1 Japan Science and Technology Agency 4-1-8 Motomachi, Kawaguchi-shi, Saitama 332-0012 (Present : Fujitsu Laboratories Ltd., 10-1 MorinosatoWakamiya, Atsugi-shi, Kanagawa 243-0197)

* 2 Japan PVC Environmental Affairs Council 1-4-1 Shinkawa, Chuou-ku, Tokyo 104-0033

* 3 Graduate School of Engineering, Tokai University 1117 Kitakaname, Hiratsuka-shi, Kanagawa 259-1292

* 4 United Nations University 5-53-70 Jingumae, Shibuya-ku, Tokyo 150-8925
考えていく上でも重要な存在である2)。このように，PVCは生 産性・経済性・リサイクル性にも優れた材料である一方で, 近 年では環境への過剩なる警戒から, 製品へのPVCの使用が制 限され，新たに代替材料を用いた製品へと移行した経緯があ る。これは, PVC製品を燃焼させた際に発生するダイオキシ ン類等の塩素系化合物による影響や, PVC中に含有される可 塑剂等による人間健康・生態系への影響による懸念が主な理 由であった。しかしながら, ある素材や製品が地球環境にも たらす影響を考える場合には，一側面からの見解だけでなく， 多角的な視点から様々な環境への影響を定量的に把握し, 総 合的に判断される必要がある。つまり, LCA (Life Cycle

* 1 (独) 科学技術振興機構

干 332-0012 埼玉県川口市本町 4-1-8

(現 (株) 富士通研究所

干 243-0197 神奈川県厚木市森の里若宮 10-1)

* 2 塩化ビニル環境対策協議会

干 104-0033 東京都中央区新川 1-4-1

* 3 東海大学工学研究科

干 259-1292 神奈川県平塚市北金目 1117

* 4 国際連合大学

干 150-8925 東京都渋谷区神宮前 5-53-70 
Assessment）手法のような総合的な環境評価手法を用いて, PVC 製品のライフサイクルにおける環境負荷を分析すること は，その素材・製品の代替性を評価する際に，判断材料の一 つとして有効と考えられる。

これまでにPVC樹脂やPVC製品のライフサイクルを通じて の環境負荷評価は幾つか報告されているが33), $\mathrm{PVC}$ 製品と代 替製品を同じ条件下において各プロセスを詳細に分析し，評 価を行った事例は少なかった。そこで本研究では，同一工場 内で製造されている特定のPVC製品と代替製品を対象にした ライフサイクルインベントリ（LCI：Life Cycle Inventory）分 析を行い, $\mathrm{PVC}$ 製品と代替製品の環境負荷排出における特性 を明らかにした上で，PVC製品のさらなる環境負荷低減に向 けた対策について検討した。

\section{2. 調査範囲と前提条件}

\section{1 対象製品}

一般にPVC製品は，“硬質製品”，“軟質製品”，“電線・その 他の製品”に大別することができるが，PVC 樹脂の製品用途 別構成を見た場合，硬質製品であるパイプ・継手が約 $38 \%$ ，次 いで軟質製品である農業用フィルム等のシート類が約 $12 \%$ と, これら製品への需要が特に大きくなっている5)。また，近年で は，これらPVC製品から代替製品への移行も著しいことから， 本研究では硬質PVC製品として水道管, さらに軟質PVC製品 として農業用フィルムを対象にして調査を行った。なお，現 状の代替製品への移行を考慮して，水道管ではポリエチレン (以下, $\mathrm{PE}$ ) 製水道管, 農業用フィルムでは PE 製農業用フィ ルムとポリエチレンテレフタレート（以下，PET）製農業用 フィルムを対象とした。

\section{2 機能単位}

水道管拉よび農業用フィルムの機能単位については, 調査 を行った製造業者において，PVC製品からの代替製品として 生産・販売が行われており，市場規模の大きな製品を選択と した。

水道管の機能単位については, 呼び径 $100 \mathrm{~mm}$ の水道管 $1 \mathrm{~m}$ の製品を対象とした。この場合，PVC 製水道管では質量：
$3.4 \mathrm{~kg} / \mathrm{m}$ ，厚み：7.1 mm，代替製品である $\mathrm{PE}$ 製水道管では質 量 : $4.2 \mathrm{~kg} / \mathrm{m}$ ，厚み: $11.4 \mathrm{~mm}$ となる。

また，農業用フィルムの機能単位は，厚み $0.15 \mathrm{~mm}$ の農業 用フィルム $1 \mathrm{~m}^{2}$ の製品を対象とし，製品の耐用年数を考慮し た上で，使用期間 1 年当たりに換算して評価を行った。この 場合，PVC 製農業用フィルムでは質量：0.186kg $/ \mathrm{m}^{2}$, 使用期 間： 4 年, 代替製品である PE 製農業用フィルムでは質量： $0.144 \mathrm{~kg} / \mathrm{m}^{2}$, 使用期間 : 5 年, PET 製フィルムでは質量： $0.206 \mathrm{~kg} / \mathrm{m}^{2}$ ，使用期間 : 10 年となる。

\section{3 システム境界と前提条件}

本LCI分析では，Fig. 1に示した“原料樹脂製造 (Stage I)”, “製品加工（Stage II）”，“リサイクル (Stage III)”，“廃棄処理 (Stage IV)”までをシステム範囲とし，リサイクル工程につい ては再生材製造までをシステムバウンダリ内に入れた。また， システム境界や原単位, シナリオ設定等の前提条件を同じに して分析するために, 調査データについては同じ文献から引 用し，またヒアリングデータについても同じ製造業者・製造 場所におけるデー夕を使用した。なお，“リサイクル（Stage III)”や“廃裹処理 (Stage IV)” のシナリオについては, 各業 界で公開されているリサイクル率等の実績值を参考に設定し た。

各ステージに拈りインベントリデータの詳細については, 以下に述べた。

\subsection{1 原料樹脂製造（Stage I）}

原料樹脂製造ステージでは，原油採取，輸入，石油精製か ら原料樹脂製造までを対象とした。各種樹脂製造に関する データをTable 1に示した。水道管㧍よび農業用フィルムにお ける代替製品における PE 樹脂製造およびPET 樹脂製造に関 するインベントリデータは, “石油化学製品のLCIデー夕調査 報告書”から引用した ${ }^{6)}$ 。また， PVC樹脂製造に関するインベ ントリデータは，PVC製品には軟質性を出すために可塑剤(フ タル酸エステル）が混合されるため，上記の文献に可塑剤製 造データを含ませている “塩化ビニル樹脂加工製品のLCIデー 夕調査報告書”を参考とした7) 8)。さらに，PE 樹脂製造デー

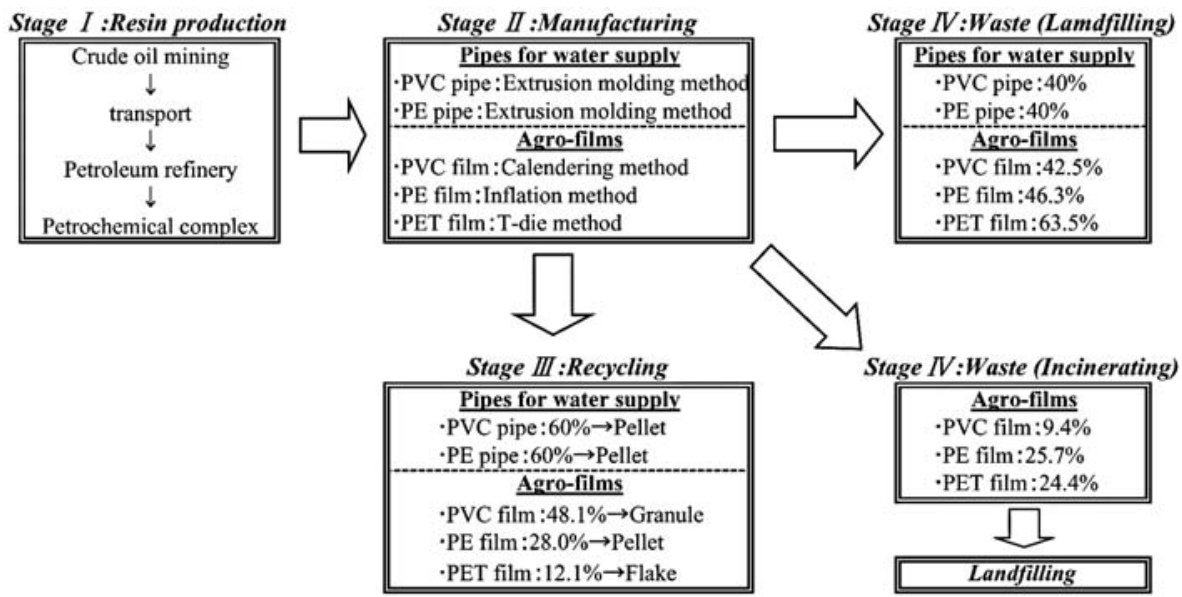

Fig. 1 System boundary of pipes for water supply and agro-films in this LCl 
Table 1 Detailed data for environmental load of resin production (Stage I)

\begin{tabular}{c|c|c|c|c|c}
\hline & $\begin{array}{c}\text { PVC resin-kg } \\
\text { (pipes for water supply) }\end{array}$ & $\begin{array}{c}\text { HDPE resin-kg } \\
\text { (pipes for water supply) }\end{array}$ & $\begin{array}{c}\text { PVC resin-kg } \\
\text { (agro-films) }\end{array}$ & $\begin{array}{c}\text { LDPE resin-kg } \\
\text { (agro-films) }\end{array}$ & $\begin{array}{c}\text { PET resin-kg } \\
\text { (agro-films) }\end{array}$ \\
\hline Process energy (kcal) & 5,675 & 4,989 & 6,237 & 5,843 & 6,052 \\
\hline Feedstock energy (kcal) & 4,600 & 10,710 & 4,722 & 10,689 & 8,301 \\
\hline $\mathrm{CO}_{2}(\mathrm{~kg})$ & 1.354 & 1.231 & 1.748 & 1.421 & 1.416 \\
\hline $\mathrm{SOx}$ (g) & 1.837 & 2.534 & 2.382 & 2.705 & 3.205 \\
\hline NOx (g) & 2.018 & 2.355 & 4.977 & 2.632 & 2.541 \\
\hline Solid waste (g) & 0.842 & 2.369 & 0.576 & 1.828 & 3.489 \\
\hline Reference & $7)$ & $6)$ & $7)$ & $6)$ & 6 ) \\
\hline
\end{tabular}

夕については，水道管用には高密度ポリエチレン (HDPE) 樹 脂，農業用フィルムには低密度ポリエチレン (LDPE) 樹脂の データを使用した。なお，各種製品では，製品特性を高める ために安定剤等の添加剤が微量ながら混入されている。しか しながら，これらに関する明確な製造データが得られなかっ たため，本調査では対象外とした。

\subsection{2 製品加工（Stage II）}

ある製品とその代替製品の定量的な評価を実施する際に， 製造業者や製造場所が異なることで，デー夕精度・信頼性の 問題が大きくなり, 適切に評価ができないことが多い。そこ で本研究では, 製品加工ステージでの水道管拉よび農業用 フィルムの加工データについては，それぞれPVC製品と代替 製品を同一工場内で製造している製造業者からインベントリ デー夕を収集した。そのデータをTable 2に示したが，水道管 の加工データについては, 原料混合 (原料貯蔵含む), 押出成 型, 冷却(ユーティリテイ含む), 切断, 積載の各工程につい て調査した。また，農業用フィルムの加工データについては， PVC製農業用フィルムはカレンダー法, PE製農業用フィルム はインフレーション法, PET製農業用フィルムはTダイ法と, それぞれ製造方法が異なるが，フィルム加工，表面塗工，巻 き取りの各工程を対象に調査を行った ${ }^{9)}$ 。

なお，以上の水道管および農業用フィルムの加工デー夕に ついては，PVC製品と代替製品の生産規模は同等で，生産量 当たりの平均值を引用した。

\subsection{3 リサイクル（Stage III）}

リサイクルステージについては，各種製品を可能な限り同 じシステム境界内で評価を行うために，再生材製造までを対
象とし，現状の各種製品のリサイクル率を反映させて調査を 実施し，そのデータをTable 3に示した。水道管のリサイクル ステージでは，PVC製水道管およびPE製水道管のリサイクル 率を $60 \%$ として，輸送（4tトラックで $1,875 \mathrm{~kg}$ 積載， $84.9 \mathrm{~km}$ 輸送), フレーク・粉砕, ペレット化 (再生材製造) までを範 囲とした ${ }^{10)}$ 。農業用フィルムのリサイクルステージでは, PVC 製農業用フィルムのリサイクル率を $48.1 \%, \mathrm{PE}$ 製農業用フィ ルムのリサイクル率を $28.0 \%$, PET 製農業用フィルムのリサ イクル率を $12.1 \%$ とし , 輸送 ( 4 tトラックで $1,875 \mathrm{~kg}$ 積載, $84.9 \mathrm{~km}$ 輸送)，グラッシュ・フレーク，ペレット化 (再生材製 造）までを範囲とした ${ }^{11)} 。$ 各工程のデータについては，PVC 製品は“塩化ビニル樹脂製品のリサイクル・処理処分のLCI調 査報告書”を，PE製品㧍よびPET製品は “プラスチック廃棄 物の処理・処分に関する LCA 調査研究報告書” を参考とし た ${ }^{12)}$ 。なお，ここで製造された再生材については，リサイク ルによってフィードストックエネルギーが保持されるものと 考え，再生材の材料エネルギーを負の材料エネルギー消費と して評価した。

\subsection{4 廃棄処理（Stage IV）}

廃衰処理ステージでは,リサイクル工程に入らなかった使 用済み製品と, リサイクルステージで発生した残渣の廃棄処 理を対象とした (Table 4 参照)。ここでの処理方法としては 焼却処理と埋立処理を対象として, 各種使用済み製品の割合 については，現状における統計デー夕を参考とした。また，各 処理施設への輸送については，4 tトラックで $1,875 \mathrm{~kg}$ 積載, $84.9 \mathrm{~km}$ 輸送とした。PVC製水道管および $\mathrm{PE}$ 製水道管の場合, リサイクル工程（リサイクル率 $60 \%$ ）に入らない $40 \%$ が直接 埋立処理されるとして，またりサイクルステージで発生した

Table 2 Detailed data for environmental load of pipes and films manufacturing (Stage II)

\begin{tabular}{c|c|c|c|c|c}
\hline & $\begin{array}{c}\text { PVC -m } \\
\text { (pipes for water supply) }\end{array}$ & $\begin{array}{c}\text { PE -m } \\
\text { (pipes for water supply) }\end{array}$ & $\begin{array}{c}\text { PVC -m2 } \\
\text { (agro-films) }\end{array}$ & $\begin{array}{c}\text { PE -m2 } \\
\text { (agro-films) }\end{array}$ & $\begin{array}{c}\text { PET -m2 } \\
\text { (agro-films) }\end{array}$ \\
\hline Process energy (kcal) & 1,979 & 5,140 & 784 & 371 & 1,574 \\
\hline $\mathrm{CO}_{2}(\mathrm{~kg})$ & 0.397 & 1.031 & 0.160 & 0.075 & 0.347 \\
\hline $\mathrm{SOx}(\mathrm{g})$ & 0.354 & 0.918 & 0.068 & 0.038 & 0.385 \\
\hline NOx $(\mathrm{g})$ & 0.375 & 0.975 & 0.190 & 0.082 & 0.477 \\
\hline Solid waste $(\mathrm{kg})$ & 0.0 & 0.0 & 0.0 & 0.004 & 0.010 \\
\hline Reference & Mearsured & Mearsured & Measured & Mesured & Measured \\
\hline
\end{tabular}


Table 3 Detailed data for environmental load of recycling process (Stage III)

\begin{tabular}{|c|c|c|c|c|c|}
\hline & $\begin{array}{c}\text { PVC -m } \\
\text { (pipes for water supply) }\end{array}$ & $\begin{array}{c}\text { PE -m } \\
\text { (pipes for water supply) }\end{array}$ & $\begin{array}{c}\text { PVC -m2 } \\
\text { (agro-films) }\end{array}$ & $\begin{array}{c}\text { PE -m2 } \\
\text { (agro-films) }\end{array}$ & $\begin{array}{c}\text { PET -m2 } \\
\text { (agro-films) }\end{array}$ \\
\hline \multicolumn{6}{|c|}{ Transport (4t-Truck) } \\
\hline Process energy (kcal) & 258.2 & 318.1 & 14.09 & 10.91 & 15.56 \\
\hline $\mathrm{CO}_{2}(\mathrm{~kg})$ & 0.073 & 0.090 & 0.004 & 0.003 & 0.004 \\
\hline SOx (g) & 0.086 & 0.106 & 0.005 & 0.004 & 0.005 \\
\hline $\mathrm{NOx}(\mathrm{g})$ & 0.224 & 0.276 & 0.012 & 0.009 & 0.013 \\
\hline \multirow[t]{2}{*}{ Reference } & 12) & 12) & 12) & 12) & 12) \\
\hline & Pulverization & Flake & Granulation & Flake & Flake \\
\hline Process energy (kcal) & 3,211 & 832.8 & 137.2 & 28.55 & 171.2 \\
\hline $\mathrm{CO}_{2}(\mathrm{~kg})$ & 0.618 & 0.164 & 0.027 & 0.006 & 0.034 \\
\hline SOx (g) & 0.563 & 0.120 & 0.020 & 0.004 & 0.025 \\
\hline $\mathrm{NOx}(\mathrm{g})$ & 0.638 & 0.138 & 0.023 & 0.005 & 0.028 \\
\hline Solid waste (kg) & 0.454 & 0.003 & 0.100 & 0.000 & 0.025 \\
\hline \multirow[t]{2}{*}{ Reference } & 5) & 12) & 5) & 12) & 12) \\
\hline & Pelletization & Pelletization & - & Pelletization & - \\
\hline Process energy (kcal) & 1,463 & 599.5 & - & 20.55 & - \\
\hline $\mathrm{CO}_{2}(\mathrm{~kg})$ & 0.311 & 0.118 & - & 0.004 & - \\
\hline SOx (g) & 0.298 & 0.086 & - & 0.003 & - \\
\hline $\mathrm{NOx}(\mathrm{g})$ & 0.379 & 0.099 & - & 0.003 & - \\
\hline Solid waste (kg) & 0.063 & 0.0 & - & 0.0 & - \\
\hline \multirow[t]{2}{*}{ Reference } & Measured & 12) & & 12) & \\
\hline & Extrusion (Fig.4 data) & - & - & - & - \\
\hline Process energy (kcal) & 3,566 & - & - & - & - \\
\hline $\mathrm{CO}_{2}(\mathrm{~kg})$ & 0.660 & - & - & - & - \\
\hline SOx (g) & 0.587 & - & - & - & - \\
\hline NOx $(g)$ & 0.623 & - & - & - & - \\
\hline Solid waste (kg) & 0.025 & - & - & - & - \\
\hline Reference & Measured & & & & \\
\hline
\end{tabular}

Table 4 Detailed data for environmental load of waste process (Stage IV)

\begin{tabular}{c|c|c|c}
\hline & $\begin{array}{c}\text { Transport } \\
(/ \mathrm{kg})\end{array}$ & $\begin{array}{c}\text { Incineration } \\
(/ \mathrm{kg})\end{array}$ & $\begin{array}{c}\text { Landfill } \\
(/ \mathrm{kg})\end{array}$ \\
\hline Process energy (kcal) & 75.74 & 73.31 & 97.47 \\
\hline $\mathrm{CO}_{2}(\mathrm{~kg})$ & 0.021 & 0.015 & 0.009 \\
\hline $\mathrm{SOx}(\mathrm{g})$ & 0.025 & 0.012 & 0.027 \\
\hline $\mathrm{NOx}(\mathrm{g})$ & 0.066 & 0.016 & 0.007 \\
\hline Reference & $12)$ & $12)$ & $12)$ \\
\hline
\end{tabular}

残渣については, 焼却処理された後, 埋立処理されるものと した。PVC製農業用フィルム，PE製農業用フィルム，PET製 農業用フィルムの場合, 焼却処理された後に埋立処理される 割合が9.4\%，25.7\%，24.4\%，直接埋立処理される割合が 42.5

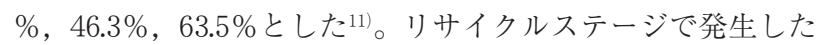
残渣についても, 焼却処理された後, 埋立処理されるものと した。これらの輸送，焼却処理，埋立処理に関するデー夕は， “プラスチック廃棄物の処理・処分に関する LCA 調査研究報 告書”を参考とした ${ }^{12)}$ 。

\section{4 環境負荷項目}

本研究では, 石油資源等の枯渇問題が懸念されているエネ ルギー消費, 地球温暖化への寄与が考えられている $\mathrm{CO}_{2}$ 排出,
酸性化に影響を及ぼしているSOx・NOx排出，最終処分場の逼 迫が問題視されている固形廃棄物を環境負荷項目とした。エ ネルギー消費量については, 工程エネルギー（プロセスエネ ルギー) と材料エネルギー（フィードストックエネルギー）と に区分して表示した。

\section{3. 結果および考察}

\section{1 水道管における環境負荷分析}

上述した調査範囲と前提条件より, PVC製水道管㧍よびPE 製水道管におけるエネルギー消費量を分析した。その結果を Fig. 2 に示したが，両水道管共に，原料樹脂製造 (Stage I) に おけるエネルギー消費量が大きく，プロセスエネルギーに限 れば，PVC 製水道管で全体の $79 \%, \mathrm{PE}$ 製水道管で全体の 76 \%を占めていた。PVC製水道管とPE製水道管のライフサイク ルでのエネルギー消費量を比較した場合, $\mathrm{PE}$ 製水道管の原料 樹脂製造におけるフィードストックエネルギーが極めて大き いことから，PVC製水道管のエネルギー消費量が小さくなる 結果が得られた。また, プロセスエネルギーのみで比較した 場合でも, PVC製水道管のエネルギー消費量がやや小さい結 果となった。製品加工 (Stage II) においてエネルギー消費量 に差が生じているが，これは PE 製水道管が PVC 製水道管に 比べ, 溶融粘度が高く, 冷却効率が低いために, エネルギー 


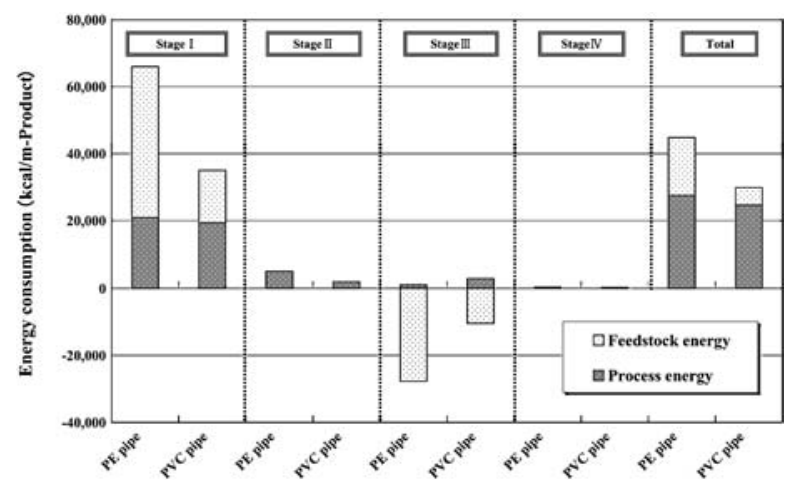

Fig. 2 Energy consumption in life cycle of pipes for water supply made from PE and PVC

消費量が大きくなるためである。両水道管共に，製品加工 (Stage II)，リサイクル (Stage III), 廃衰処理（Stage IV）に おけるエネルギー消費量は相対的に小さく，水道管のライフ サイクルにおけるエネルギー消費量が原料樹脂製造 (Stage I) に大きく依存していることから，ここでのエネルギー削減対 策が重要であることが示唆された。

次に, $\mathrm{PVC}$ 製水道管およびPE製水道管のライフサイクルに おける $\mathrm{CO}_{2}$ 排出量, SOx排出量, NOx排出量および固形廃棄物 量の結果をFig. 3に示した。この結果に执いても，エネルギー 消費量の結果と同様に, $\mathrm{PE}$ 製水道管からの $\mathrm{CO}_{2}$ 排出量, $\mathrm{SOx}$ 排出量, NOx 排出量が大きくなり，これらは原料樹脂製造に 起因する排出であった。固形廃棄物量については，わずかに $\mathrm{PVC}$ 製水道管が小さいが，大きな差はなかった。

さらに，PVC製水道管については，クローズド(Pipe to Pipe) リサイクルが行われた場合のエネルギー消費量についても試 算を行った。PVC製水道管とPE製水道管における大きな違い は，PE製水道管はカスケード・リサイクルが行われるのに対 して，PVC製水道管ではクローズド・リサイクルが行われ，社 会的にもシステムが確立している点にある。したがって，再 生材製造 (ペレット化) までの PVC 製水道管のシステムバウ ンダリを，その後の押出成形工程まで拡大して分析を行った (Table 3参照)。なお，ここで定義するリサイクル率とは，使 用済みになった水道管がリサイクル工程において処理される

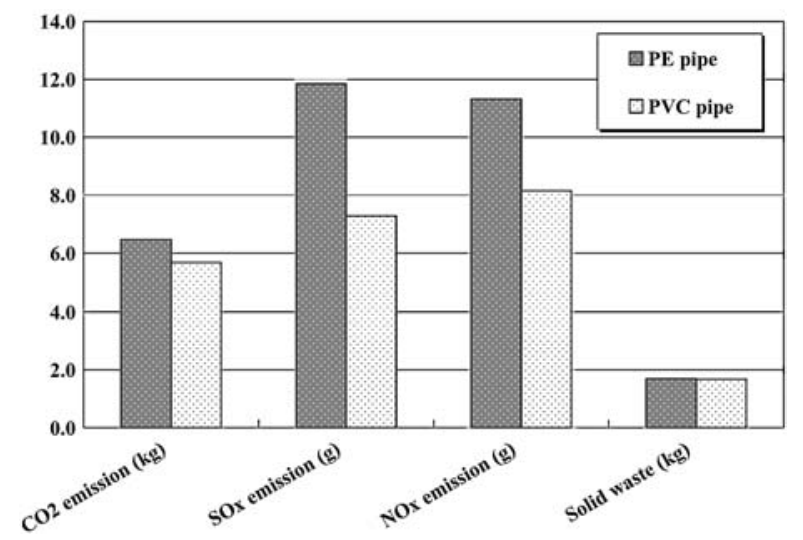

Fig. 3 Environmental loads in life cycle of pipes for water supply made from PE and PVC

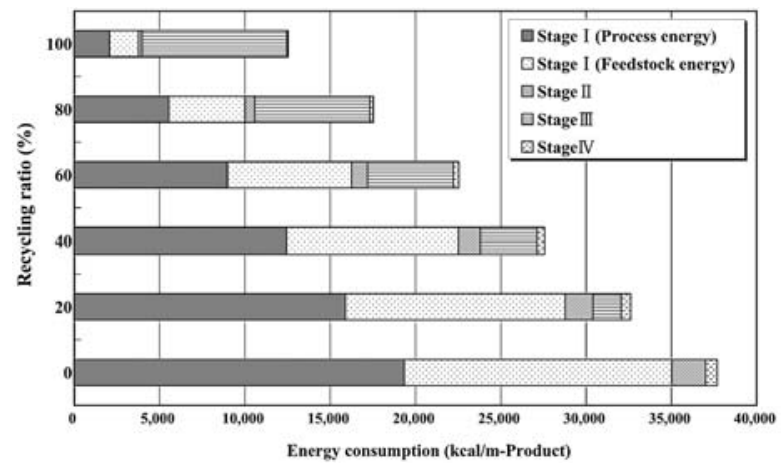

Fig. 4 Relationship between recycling ratio and energy consumption of pipe for water supply made from PVC

重量比率とした。またリサイクルによって保持されるフィー ドストックエネルギーは，クローズド・リサイクルによって 再生される水道管のフィードストックエネルギーとして相殺 されるものと考えた。PVC製水道管のライフサイクルにおけ るエネルギー消費量とリサイクル率 (Pipe to Pipe 率) の関係 をFig. 4 に示したが，リサイクル率が高くなるに従って，著 しくエネルギー消費量が減少する結果が得られた。特に，リ サイクル率100\%のPVC製水道管は，リサイクルを行わなかっ た場合と比較して，リサイクル工程でのエネルギー消費量が 増加するものの，ライフサイクル全体でのエネルギー消費量 を $67 \%$ 削減できることが示された。また, Pipe to Pipeリサイ クルを行うことで，大部分を占めていた原料樹脂製造 (Stage I）におけるエネルギー消費量を約 $90 \%$ 削減できることが確認 された。

以上の結果から，クローズド・リサイクルの促進は，ライ フサイクル全体でのエネルギー消費量を大幅に削減できるこ とから，原料樹脂製造（Stage I）でのエネルギー削減対策と 共に，今後のPVC製水道管の環境負荷低減に向けた対策の一 つとして考えられる。

\section{2 農業用フィルムにおける環境負荷分析}

PVC製農業用フィルム，PE製農業用フィルムおよびPET製 農業用フィルムに抢けるエネルギー消費量について，製品の 耐用年数を考慮して分析を行った。農業用フィルムは，野外 で長時間使用されることから，天候等による影響を受けやす く, 定期的に交換が必要な製品である。製造業者によれば, PVC 製農業用フィルムは 4 年, PE 製農業用フィルムは 5 年, PET製農業用フィルムは 10 年の耐用年数とされており，これ らの使用期間を 1 年当たりに換算してエネルギー消費量を算 出した。その結果を Fig. 5 に示したが，水道管の結果と同様 に, $\mathrm{PVC}$ 製農業用フィルムと $\mathrm{PE}$ 製農業用フィルムでは，原料 樹脂製造（Stage I）におけるエネルギー消費量が大きく，プ ロセスエネルギーに限れば，それぞれ全体の59\%，69\%を占 めていた。これに対して, PET 製農業用フィルムでは, 製品 加工（Stage II）におけるエネルギー消費量が大きくなり，プ ロセスエネルギーの $53 \%$ を占める結果となったが，これは フィルム加工方法の違いに起因するものと考えられる。また, PVC 製農業用フィルム，PE 製農業用フィルムおよび PET 製 


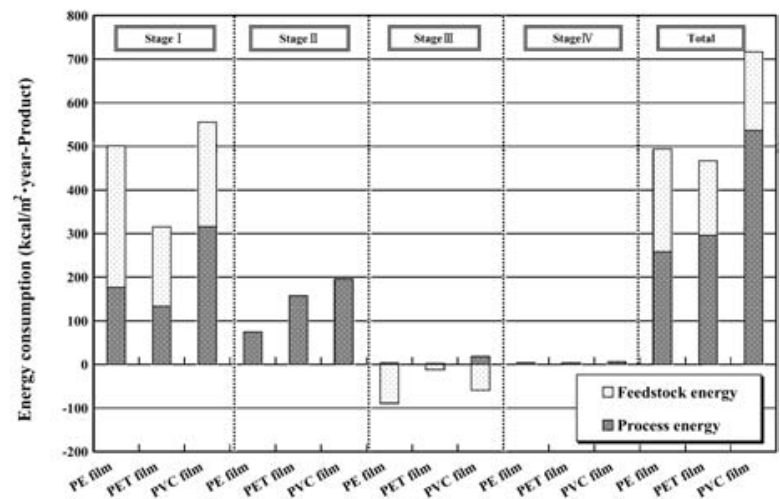

Fig. 5 Energy consumption per a year of agro-films made from PE, PET and PVC

農業用フィルムのライフサイクルにおけるエネルギー消費量 の比較では，使用期間の最も長いPET製農業用フィルムが最 も小さくなり，プロセスエネルギーのみの評価では，PE製農 業用フィルムが最も小さくなる結果が示された。使用期間の 最も短いPVC製農業用フィルムのエネルギー消費量が著しく 大きくなる結果が得られたことから, PVC製農業用フィルム の課題が耐用年数の向上にあると考えられる。

次に, PVC製農業用フィルム, PE製農業用フィルムおよび PET製農業用フィルムのライフサイクルにおける $\mathrm{CO}_{2}$ 排出量, SOx排出量, NOx排出量および固形廃棄物量の結果をFig. 6に 示した。その結果, $\mathrm{PE}$ 製農業用フィルムの $\mathrm{CO}_{2}$ 排出量, $\mathrm{SOx}$ 排出量, NOx 排出量が最も小さくなることが確認された。そ れに対して, PVC製農業用フィルムは, 全ての環境負荷項目 で大きくなり，特にNOx排出量で極めて大きく，これは原料 樹脂製造 (Stage I)，特に可塑剤製造に起因するものであった。 そこで，PVC製農業用フィルムの耐用年数を現状の 2 倍 $(8$ 年）に延長した場合を想定して，エネルギー消費量について 試算を行った。その結果を Fig. 7 に示したが，PVC製農業用 フィルムの使用期間を延長させることで，PE製農業用フィル ムよりも $27.5 \%$, PET 製農業用フイルムよりも $23.2 \%$ の不 ルギー消費量を削減できることが示された。PVC 製農業用 フィルムに扔ける代替製品とのエネルギー消費量の差は，プ ロセスエネルギーにおいては小さいものの，フィードストッ

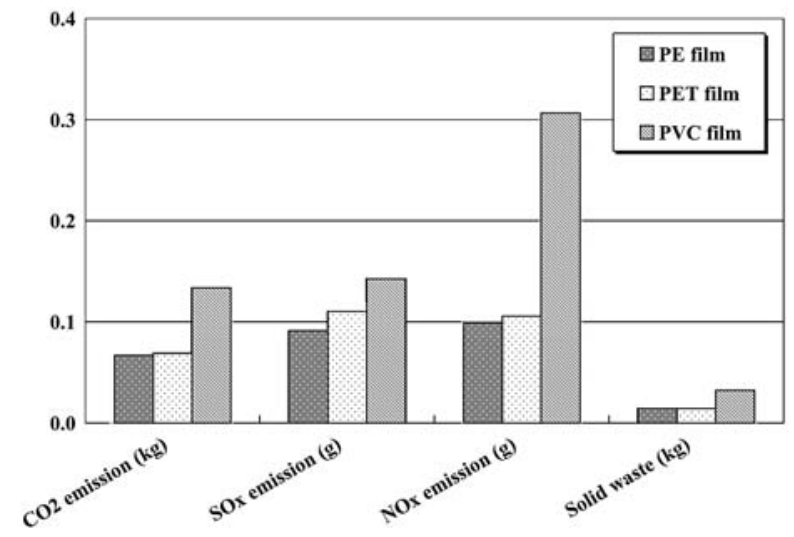

Fig. 6 Environmental loads per a year of agro-films made from PE, PET and PVC

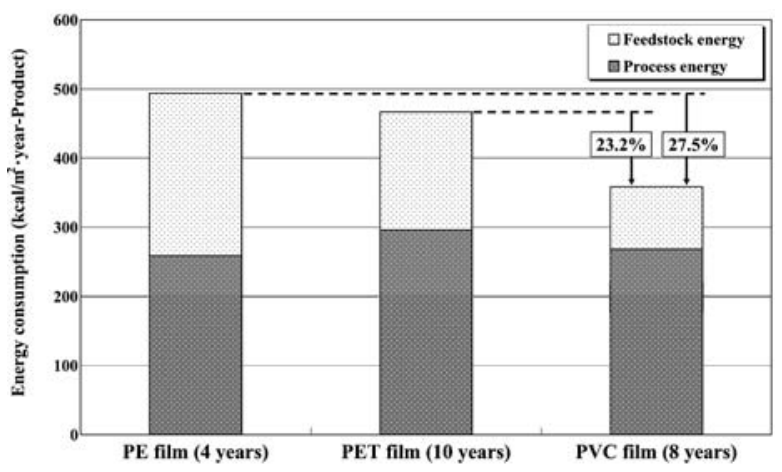

Fig. 7 Reduction effect of energy consumption from PVC agrofilm by extending life period

クエネルギーにおいて特に大きくなることが確認された。

以上の結果から, PVC 製農業用フィルムの耐用年数を延ば すことが可能になれば，単位年当たりのエネルギー消費量の 低減化を図れることが示されたことから，今後は使用期間の 長期化が環境負荷低減へ向けての一施策になるものと推察さ れた。ただし，上記の試算では，農業用フィルムへの技術的 対策（例えば，フイルム表面のコーティング処理等）に係わ る環境負荷は見積もられて抢らず，ここでのプロセスエネル ギーを考慮した上で，さらなる検証が必要と考えている。

\section{4. まとめ}

硬質 PVC 製品として水道管，軟質 PVC 製品として農業用 フィルムを対象として LCI 分析を行い, PVC 製品と代替製品 の環境負荷排出における特性を明らかにした上で, PVC製品 のさらなる環境負荷低減に向けた対策について検討し, 以下 のような結論を得た。

(1) 水道管のライフサイクルでのエネルギー消費量の比較で は，PVC製水道管のエネルギー消費量が小さいものの，原 料樹脂製造におけるエネルギー消費量に依存する結果が得 られたことから，ここでのエネルギー削減対策が重要であ ることが示唆された。

(2) PVC製水道管のPipe to Pipeリサイクルによる効果を分析し た結果, クローズド・リサイクルの促進は, ライフサイク ル全体でのエネルギー消費量を大幅に削減できることか ら，今後のPVC製水道管の環境負荷低減に向けた対策の一 つとして考えられた。

(3) 農業用フィルムのライフサイクルでのエネルギー消費量の 比較では，使用期間の最も長いPET製農業用フィルムが小 さくなり, 使用期間の最も短いPVC製農業用フィルムが大 きくなる結果が示され, PVC製農業用フィルムの耐用年数 の向上が課題として考えられた。

（4）PVC製農業用フィルムの使用期間を延長した場合を想定し てエネルギー消費量を分析した結果，代替製品よりもエネ ルギー消費量を削減できることが示されたことから, PVC 製農業用フィルムの使用期間の長期化が環境負荷低減へ向 けての一施策になるものと推察された。 


\section{文 献：References}

1）塩ビ工業・環境協会，塩ビファクトブック (2005): Vinyl Environmental Council, PVC Fact Book (2005)

2）環境省, 循環型社会形成推進基本計画 (2003): Ministry of the Environment, Basic Plan for Establishing a Sound Material-Cycle Society (2003)

3）成田暢彦, 稲葉敦, 石油学会誌, 43(3), 3(2000): Narita, N., Inaba, A., Journal of the Japan Petroleum Institute, 43 (3), 3 (2000)

4）ケムシステムズ社調査報告書, 塩化ビニル樹脂製品のライ フサイクル評価(1995): Chem Systems Survey Report, Life Cycle Assessment of Polyvinyl Chloride Products(1995)

5）塩ビ工業・環境協会，塩化ビニル樹脂製品のリサイクル 処理処分の LCI 調查報告書 (2001): Vinyl Environmental Council, Report on Investigation of LCI Concerning Recycling and Waste Management of PVC Products (2001)

6) (社) プラスチック処理促進協会, 石油化学製品のLCIデー 夕調査報告書 (1999): Plastic Waste Management Institute, Survey Report for LCI Data of Petrochemical Products (1999)

7）塩化ビニル環境対策協議会，塩化ビニル樹脂加工製品の
LCI デー夕調查報告書 (1999): Japan Environmental Affairs Council, Report on Investigation of LCI Data Concerning PVC Products (1999)

8）(社)化学経済研究所, 基礎素材のエネルギー解析調查報告 書 (1993) : Chemical Economy Research Institute, Report of Energy Analysis on Basic Materials (1993)

9）（社）プラスチック処理促進協会，樹脂加工におけるインベ ントリデー夕調查報告書 (2000): Plastic Waste Management Institute, Survey Report for Inventory Data of Plastic Processing (2000)

10）塩化ビニル管・継手協会, http://www.ppfa.gr.jp/index. html (2006): Japan PVC Pipe and Fittings Association (2006)

11）（社）日本施設園芸協会, 施設と園芸，124(2004)：Japan Greenhouse Horticulture Association, Shisetsu-to-Engei, 124 (2004)

12）(社) プラスチック処理促進協会, プラスチック廃棄物の処 理・処分に関するLCA 調査研究報告書 (2001): Plastic Waste Management Institute, Survey Report of LCA study for Recycling and Waste Management of Plastics(2001) 